Volume I Tahun 2021

November 2021
E-ISSN: 2808-5361

http://e-journal.fkmumj.ac.id/
Proceeding The First

Muhammadiyah InternasionalPublic Health and Medicine

Conference

\title{
Impact of Stigma and Community Behavior on Covid-19 Survivors: Literature Review
}

\author{
Ratih Suryandari \\ Master of Public Health Program of Public Health Faculty, University Muhamadiyah Jakarta, \\ K.H. Ahmad Dahlan St, Cireundeu, Ciputat South Jakarta, 151419 \\ Email: drg.ratihsuryandari@gmail.com
}

\begin{abstract}
Coronavirus disease or Covid-19 is a viral infection that was first discovered in Wuhan City, China at the end of 2019. The rapid spread of the disease, the absence of a cure, accompanied by a flood of information through social media, not all of which can be trusted have caused a stigma for people related to Covid-19. The study aims to determine the impact of stigma and community behavior on Covid-19 survivors. The research method uses a literature review, searching for data sourced from PubMed, Google Scholar, Proquest, and Ebsco from March-May 2021. Data analysis was carried out descriptively. The results show that there is an increasing number of reports of public stigmatization of survivors from various environments such as family and work. Stigma arises in social behavior such as ostracizing survivors, refusing and ostracizing people who move from one area to another, ostracizing medical personnel who work in hospitals, refusing corpses because they are considered to have a virus that can be transmitted. Based on these observations, the authors conclude that the freedom of the media in presenting news to give different opinions to everyone, the lack of health educators, the number of hoax news that spread, and the different policies of the central and regional governments that make it difficult to control disease and have an impact on Covid-19 survivors in Indonesia. . rejected the corpse because it was considered that there was still a virus that could be transmitted. Based on these observations, the authors conclude that the freedom of the media in presenting news to give different opinions to everyone, the lack of health educators, the number of hoax news that spread, and the different policies of the central and regional governments that make it difficult to control disease and have an impact on Covid-19 survivors in Indonesia. . rejected the corpse because it was considered that there was still a virus that could be transmitted. Based on these observations, the authors conclude that the freedom of the media in presenting news to give different opinions to everyone, the lack of health educators, the number of hoax news that spread, and the different policies of the central and regional governments that make it difficult to control disease and have an impact on Covid-19 survivors in Indonesia.
\end{abstract}

Keywords: Covid-19, Community, Behavior, Stigma, Survivors. 


\section{INTRODUCTION}

In early 2020, the incidence of severe infections with unknown causes shocked the world, starting with China reporting to the World Health Organization (WHO) because there were 44 patients with severe pneumonia in the Wuhan City area, Hubei Province, China. Initial allegations are related to the existence of a wet market that sells fish, marine animals, and various other animals. The cause was identified on January 10, 2020, and the genetic code is the new coronavirus (Handayani, et al, 2020)

Subsequent research showed that there was a close relationship with the coronavirus that caused Severe Acute Respiratory Syndrome (SARS) in 2003 which at that time was endemic in Hong Kong (Ceraolo \& Giorgi, 2020) until WHO gave the name novel coronavirus (nCoV-19) (Zhou, Yang, 2003). , Wang, et al, 2020).

In most cases, Covid-19 causes mild symptoms such as dry cough, fatigue, fever, aches and pains, stuffy nose, runny nose, sore throat, or diarrhea. Some people are infected but without any symptoms. Some people recover without special treatment (WHO, 2021).

Information about this virus is constantly changing because many things are still under research and epidemiological data will be developing as well, for this reason, the review is based on the limited information that is summarized to provide limited information which is summarized to provide information and there may be changes in policy and related matters. others according to the development of research results, epidemiological data, and progress of diagnosis and therapy (Zhu, Zhang, et al, 2020).

There is an increase in the number of reports of public stigmatization of Covid-19 survivors, especially for people from areas affected by the epidemic. Stigma appears in social behavior such as ostracizing survivors, refusing and ostracizing people who move from one region to another, ostracizing certain ethnicities because they are considered carriers of the virus, ostracizing medical personnel who work in hospitals, refusing corpses because they are considered to have viruses that can be transmitted. Stigma occurs when a person negatively associates an infectious disease, such as Covid-19, with a specific population. In the case of Covid-19, stigma attacks people who come from infected areas/regions. Currently, stigma is present in the form of labeling, stereotyping, segregation, deprivation of status, and discrimination against people connected to Covid-19.

As a new disease that spreads quickly and can lead to death, accompanied by a flood of information through social media, not all of which can be trusted, it has created a stigma for people associated with Covid-19. 


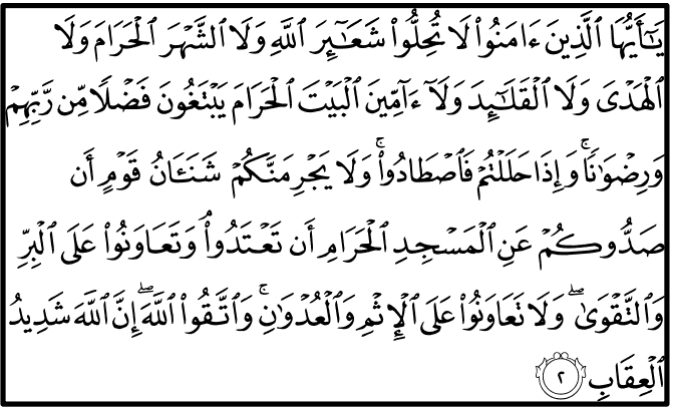

Meaning: "And help you in goodness and piety. And do not help in sin and transgression. And fear Allah, verily Allah's punishment is severe." (Surat al-Maidah: 2).

\section{METHODS}

This study aims to determine the impact of stigma and community behavior on Covid-19 survivors through a literature review by searching for data sourced from PubMed, Ebsco, Proquest, and Google Scholar from March-May 2021 using the keyword Covid-19 stigma. To answer the research problems proposed by the author, including the impact of negative stigma on Covid-19 survivors and how to take action to overcome it. The nature of the study carried out is descriptive analysis, namely providing education and understanding to the reader, and the type of data used in the study is secondary data.

\section{RESULTS AND DISCUSSION}

Stigma is a term that describes a situation related to the point of view of something that has a negative value. Stigma in the context of health is a negative relationship between a person or group of people who share certain characteristics and diseases (WHO, 2021). Things that can occur due to stigma include 1) Patients hide their illness because they avoid discrimination, 2) Patients delay immediate treatment, 3) It is difficult for sufferers to behave healthily. The stigma of some and disorders is a central issue in public health (Septiawan, n Mulyani \& Susanti, 2018).

At the beginning of 2020, along with the emergence of the global Covid-19 pandemic, it also added to the row of diseases that caused negative stigma for sufferers and their families. Covid-19 is a disease that can spread very quickly and can cause death. Moreover, the Covid-19 drug has not been found at this time.

Corona Virus Disease 2019 (Covid-19) is a respiratory infection caused by the Severe Acute Respiratory Syndrome Coronavirus-2 or SARS-CoV-2. Some exposed people have only mild or no symptoms, about $14 \%$ have a severe illness requiring hospitalization requiring oxygen support, and $5 \%$ need to be admitted to an intensive care unit (NCPERE, 2020). The condition of Covid-19 can worsen if there are comorbid factors such as hypertension, diabetes mellitus, and cardiovascular disease (Satria, et al, 2020). 
Covid-19 is a "taboo", survivors experiencing long covid can face distrust from doctors, superiors, and even their own families (CNN, 2020). In their daily lives, Covid-19 survivors grapple with social stigma, including from their family environment, one of which is the lack of educational campaigns regarding this issue (Hidayat, 2021).

The terms used in handling the Covid-19 pandemic from people under monitoring (ODP), patients under surveillance (PDP), and people without symptoms (OTG) have changed into Suspected Cases, Confirmed Cases (symptomatic and asymptomatic), and Contacts. Closely (Ministry of Health, 2020).

\section{Suspect Case}

a. Persons with Acute Respiratory Tract Infection (ARI) and in the past 14 days have a history of travel or living in an area reporting local transmission

b. People with one of the symptoms of ARI and in the last 14 days have a history of contact with a confirmed case of Covid-19

c. People with severe ARI/severe pneumonia requiring hospitalization and no other causes based on convincing clinical features

2. Confirmation Case; tested positive for the Covid-19 virus as evidenced by the RT-PCR laboratory examination. It is divided into two namely:

a. Confirmed cases with symptoms (Symptomatic); to find close contacts the contact period is calculated from 2 days before the case develops symptoms to 14 days after the case develops symptoms

b. Asymptomatic confirmed cases (asymptomatic); to find close contacts the contact period is calculated from 2 days before the case develops symptoms to 14 days after the date of collection of the confirmed case specimen

3. Close Contact; people who have a history of close contact with confirmed/probable cases.

The contact history in question includes:

a. Face-to-face contact/adjacent to confirmed cases within the 1-meter radius and 15 minutes or more

b. Direct physical touch with confirmation cases (such as shaking hands, holding hands, etc.)

c. People who provide direct care for confirmed cases without using PPE according to standards

d. Other situations that indicate contact are based on a local risk assessment established by the local epidemiological investigation team. 
Some of the criteria for completing isolation, recovering, and returning home (Covid-19 Management Guidelines, 2020):

\begin{tabular}{|c|c|c|}
\hline No. & Criteria & Explanation \\
\hline 1. & $\begin{array}{l}\text { Criteria for completion of } \\
\text { isolation }\end{array}$ & $\begin{array}{l}\text { a. Confirmed cases without symptoms (asymptomatic), with mild } \\
\text { and moderate symptoms: no follow-up RT-PCR examination. It } \\
\text { is declared complete if it has undergone isolation for } 10 \text { days } \\
\text { from the date of onset plus at least } 3 \text { days after no longer } \\
\text { showing symptoms of fever and respiratory problems. } \\
\text { b. Moderate symptom confirmation cases with comorbid and/or } \\
\text { potentially worsening symptoms can be re-evaluated by RT- } \\
\text { PCR. } \\
\text { c. Confirmed cases with severe/critical symptoms who are } \\
\text { hospitalized; } \\
\text { 1. Completed isolation if the results of the follow-up RT-PCR } \\
\text { examination are negative } 1 \text { time plus a minimum of } 3 \text { days } \\
\text { no longer showing symptoms of fever and respiratory } \\
\text { problems } \\
\text { If a follow-up RT-PCR examination cannot be carried out, } \\
\text { patients who have been isolated for } 10 \text { days from the onset } \\
\text { plus at least } 3 \text { days without symptoms of fever and } \\
\text { respiratory problems, are declared complete isolation and } \\
\text { can be transferred to non-isolation care or sent home. }\end{array}$ \\
\hline
\end{tabular}

2. Criteria for recovery

3 Return criteria
Confirmed patients with no symptoms, mild symptoms, moderate symptoms, and severe/critical symptoms are declared cured if they have fulfilled the criteria for completing isolation and a statement is issued after monitoring, based on the assessment of the doctor at the health facility where the monitoring was carried out or by the DPJP.

Confirmed patients may have positive persistent RT-PCR follow-up examination results because the RT-PCR examination can still detect body parts of the Covid-19 virus even though the virus is no longer active (no longer infecting) the patient, the determination of recovery is based on the results of the assessment carried out. carried out by the DPP.

Patients can be discharged if they meet the criteria for completion of isolation and meet the following clinical criteria:

1. Radiological findings and blood tests show improvement

2. No other action needed

Specifically, confirmed patients with severe/critical symptoms who have been discharged will continue to self-isolate for at least 7 days to recover and be alert to the emergence of Covid-19 symptoms and consistently implement health protocols.

Social stigma in the context of health is a negative association between a person or group of people who share certain characteristics and diseases. In an outbreak, social stigma means that people are labeled, stereotyped, discriminated against, treated differently, and/or experience a loss of status because they are considered to have a connection with a disease.

This kind of treatment will have a negative impact not only on people with the disease but also on nurses, family, friends, and the community. The Covid-19 outbreak has triggered social 
stigma and discriminatory behavior against people from certain ethnic backgrounds as well as for anyone suspected of having been exposed to the Covid-19 virus.

The level of Covid-19 stigma is related to three main factors, including 1) Covid-19 is a new disease and there are still many unknowns; 2) Fear of the unknown, and 3) Fear of being associated with 'others'.

Stigma can undermine social cohesion and lead to the possible social isolation of the group, which can contribute to situations that can lead to more severe health problems and difficulty controlling disease outbreaks. Stigma can encourage people to hide illness so as not to be discriminated against, can prevent people from seeking health care immediately, and can prevent them from adopting healthy lifestyles.

Evidence shows that stigma and fear around infectious diseases hinder response, while helpful actions are to build trust in health services and facilities, show empathy for those affected, understand the disease itself and take practical and effective steps so that people can help protect themselves. themselves and their loved ones to stay safe.

Some examples of cases received by Covid-19 survivors (Hidayat, 2021):

1. Wage cuts or even some that are not paid a dime

2. Curing Covid-19 is the same as RT-PCR negative. The policies used by some companies and the RT-PCR costs are borne by employees personally

3. Dismissal for being considered unproductive by the company

\section{CONCLUSION AND SUGGESTIONS}

An increasing number of reports of public stigmatization of survivors from various environments such as family and work. Stigma arises in social behavior such as ostracizing survivors, refusing and ostracizing people who move from one area to another, ostracizing medical personnel who work in hospitals, refusing corpses because it is considered that there is still a virus that can be transmitted.

How to communicate about Covid-19 is critical in supporting people to take effective action to help fight the disease and to avoid fear and stigma. Create an environment in which disease and its effects can be discussed and addressed openly, honestly, and effectively.

Governments, citizens, media, influencers, and communities have an important role to play in preventing and stopping stigma. Here are some examples and tips on actions that can be taken to fight stigmatization:

a. Spreading the facts: Stigma is exacerbated by a lack of knowledge about how Covid19 is transmitted and treated and how to prevent it. Social media is currently useful for conveying health information to many people at a relatively low cost (Fayoyin, 2014). 
E-ISSN: 2808-5361

http://e-journal.fkmumj.ac.id/
Proceeding The First Muhammadiyah InternasionalPublic Health and Medicine Conference

b. Involving social influencers such as leaders, religious leaders, celebrities to communicate to reduce stigma. Do not forget to adapt to the customs and culture of each.

c. Speak up to Covid-19 survivors that most people can recover. Campaign for medical heroes so as not to be affected by stigma

d. Covering various ethnic groups does not refer to a particular group

e. Ethical journalism: Not focusing on the people exposed can spread Covid-19, suggesting that this virus cannot be stopped. Should promote content on how to prevent basic infections, symptoms of Covid-19, and when to seek health care.

f. Connecting: Initiatives against stigma and stereotypes. Connecting activities that become movements and a positive environment that shows concern and empathy for all.

"Infodemic" Misinformation and rumors spread faster than the current Covid-19 outbreak. This exacerbates negative effects including stigmatization and discrimination against Covid-19 survivors. Collective solidarity and clear, actionable information are needed to support Covid-19 survivors.

As for some communication tips and messages that can be conveyed, among others:

a. Misconceptions, rumors, and misinformation contribute to stigma and discrimination that hinder response efforts

b. Collective solidarity and global cooperation are needed to prevent further spread and allay people's concerns

c. Facts will stop the spread of Covid-19 not fear 


\section{REFERENCES}

Ceraolo, C \& Giorgi, FM. 2020. Genomic variance of the 2019-nCoV coronavirus. J Med Virol; 92:522-8.

CNN, 2020. Talk to Covid-19 Survivors Who Experienced Effects After Recovering. Accessed April 26, 2021 viahttps://www.cnnindonesia.com/gaya-Life/20201202095241-255-576935/curhatpara-penyintas-covid-19-yang-alami-effects-usai-sembuh

Fayoyin, A. 2016. Engaging social media for health communication in Africa : Approaches, results and lessons. Journal of Mass Communication and Journalism, 6: 315.

Handayani, et al. 2020. Corona Virus Disease 2019. Indo Respira Journal Vol. 40 No. 2:119-129.

Hidayat R, 2021. Long Covid Survivors Fight Alone and Face Social Stigma. Accessed April 26, 2021 viahttps://tirto.id/penyintas-long-covid-berjuang-diri-dan-facing-stigma-social-gbwC

Livana PH, Setiawati L, Sariti I. 2020. Stigma and Community Behavior in Covid-19 Positive Patients. Journal of Emergency Vol.2 No.2:95-100.

NCPERE, T. 2020. The Epidemiological Characteristics of an Outbreak of 2019 Novel Coronavirus Disease (Covid-19). China, 2(x), 1-10.

Covid-19

Management Guidelines,

2020

Edition

3.https://www.papdi.or.id/pdfs/983/Buku\%20Pedoman\%20Tatalaksana\%20COVID-

19\%2050P\%20Edisi\%203\%202020.pdf

Satria RMA, Tutupoho RV, Chalidyanto D, 2020. Analysis of Risk Factors for Death with Comorbid Covid-19 Diseases. Silampari Journal of Nursing. Vol 4 No. 1.

Septiawan L,.F., Mulyani, S and Susanti, 2018. Stigma of patient leader in Sumberarum Village

District danden District Bojonegoro year 2017.

http://ejournal.rajekwesi.ac.id/index.php/jurnalpenelitiankesehatan/article/download/173/134.

WHO. 2021. What is Corona Virus? Accessed viahttps://www.who.int/healthtopics/coronavirus\#tab=tab 1 on March 26, 2021.

Zhou P, Yang X, Wang X, et al. 2020. A Pneumonia outbreak associated with a new coronavirus of probable bat origin. Nature 579:270-3.

Zahu N, Zhang D, Wang W, Li X, Yang B, Song J, et al. 2019. A Novel coronavirus from patients with pneumonia in China. N Engl J Med; 382:727-33. 